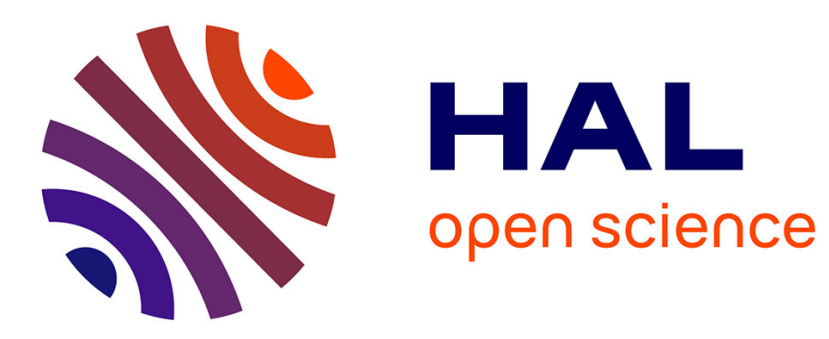

\title{
Risk of invasive breast cancer after lobular intra-epithelial neoplasia: Review of the literature
}

Yan Ansquer, Sarah Delaney, Pietro Santulli, Laurence Salomon, Bruno

Carbonne, Remy Salmon

\section{- To cite this version:}

Yan Ansquer, Sarah Delaney, Pietro Santulli, Laurence Salomon, Bruno Carbonne, et al.. Risk of invasive breast cancer after lobular intra-epithelial neoplasia: Review of the literature. EJSO - European Journal of Surgical Oncology, 2010, 36 (7), pp.604. 10.1016/j.ejso.2010.05.019 . hal-00603543

\section{HAL Id: hal-00603543 \\ https://hal.science/hal-00603543}

Submitted on 26 Jun 2011

HAL is a multi-disciplinary open access archive for the deposit and dissemination of scientific research documents, whether they are published or not. The documents may come from teaching and research institutions in France or abroad, or from public or private research centers.
L'archive ouverte pluridisciplinaire HAL, est destinée au dépôt et à la diffusion de documents scientifiques de niveau recherche, publiés ou non, émanant des établissements d'enseignement et de recherche français ou étrangers, des laboratoires publics ou privés. 


\section{Accepted Manuscript}

Title: Risk of invasive breast cancer after lobular intra-epithelial neoplasia: Review of the literature

Authors: Yan Ansquer, Sarah Delaney, Pietro Santulli, Laurence Salomon, Bruno Carbonne, Remy Salmon

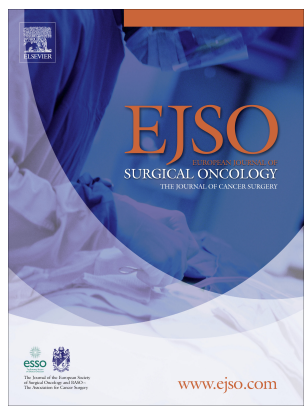

PII: S0748-7983(10)00127-7

DOI: 10.1016/j.ejso.2010.05.019

Reference: $\quad$ YEJSO 2981

To appear in: European Journal of Surgical Oncology

Received Date: 22 February 2010

Revised Date: 11 May 2010

Accepted Date: 17 May 2010

Please cite this article as: Ansquer Y, Delaney S, Santulli P, Salomon L, Carbonne B, Salmon R. Risk of invasive breast cancer after lobular intra-epithelial neoplasia: Review of the literature, European Journal of Surgical Oncology (2010), doi: 10.1016/j.ejso.2010.05.019

This is a PDF file of an unedited manuscript that has been accepted for publication. As a service to our customers we are providing this early version of the manuscript. The manuscript will undergo copyediting, typesetting, and review of the resulting proof before it is published in its final form. Please note that during the production process errors may be discovered which could affect the content, and all legal disclaimers that apply to the journal pertain. 


\title{
Risk of invasive breast cancer after lobular intra-epithelial
}

\author{
neoplasia: review of the literature
}

Yan Ansquer (MD, PhD)*, Sarah Delaney (MD)*, Pietro Santulli (MD)*, Laurence Salomon $(\mathrm{MD}, \mathrm{PhD})^{* *}$, Bruno Carbonne (MD)*, Remy Salmon (MD)***

*Hôpital St Antoine/ Assistance Publique Hôpitaux de Paris, Université Pierre et Marie Curie, Paris VI/ Service de Gynécologie Obstétrique/ 184 rue du Faubourg St Antoine/ 75012 Paris. France.

**Hôpital Louis Mourier/ Assistance Publique Hôpitaux de Paris, Université Paris VII/ Département de Santé Publique/ 178 rue des Renouillers/ 92701 Colombes Cedex . France ***Institut Curie/ Département de chirurgie/ 26 rue d'Ulm/ 75005 Paris

Correspondance to: Yan Ansquer. Hôpital St Antoine/ Service de Gynécologie Obstétrique/ 184 rue du Faubourg St Antoine/ 75571 Paris Cedex 12. France. Tel 00331492827 22. Fax 00331492829 74. e-mail: yan.ansquer@sat.aphp.fr

Running title : Breast cancer risk after lobular intraepithelial neoplasia 


\section{Abstract}

Objective: Lobular intraepithelial neoplasia (LIN) is a rare breast disease that has been regarded alternately as a risk factor for invasive breast cancer in both breasts or a true breast cancer precursor. The controversy is largely dependent on the estimation of the IBC (Invasive Breast Cancer) risk after LIN; however a systematic review of the published data has not been previously performed. We aimed to review the IBC after LIN and the characteristics of those cancers.

Methods: a PubMed search was performed to identify the published articles in English addressing the breast cancer risk after LIN.

Results: There was a wide range in the figures estimating the risk of the breast cancer among the 22 studies that form the basis of this review. The cumulative average risk of invasive breast cancer (IBC) was $8.7 \%$ (range 0-33). It was $4.7 \%$ (range 0-25) for the ipsilateral and $4.2 \%$ (range $0-16$ ) for the contralateral breast. $52 \%$ of the breast cancers occurred more than 10 years after the initial LIN. A lobular histotype was present in $30 \%$ (range 0 to $67 \%$ ) of all IBC.

Conclusions: LIN should be considered both as a risk factor (low and similar level of IBC risk for both breasts, long delay between LIN and IBC) and a precursor for IBC (overrepresentation of lobular histotype).

Keywords: lobular intraepithelial neoplasia, lobular carcinoma in situ, atypical lobular hyperplasia, breast cancer, review 


\section{Introduction}

Lobular intra-epithelial neoplasia (LIN), which comprises atypical lobular neoplasia and lobular carcinoma in situ, is a rare disease characterised by non invasive lobular breast proliferation [1].

The incidence of LIN, has increased dramatically in recent years, at least partly due to the widespread uptake of mammographic screening [2].

Since the first description of LIN in 1941 [3], its treatment has remained controversial; ranging from simple biopsy $[4,5,6,7]$ to ipsilateral mastectomy and contralateral biopsy [8], or even bilateral mastectomy [9]. The treatment choice has largely been dependent on the estimation of the invasive breast cancer risk and on whether LIN was considered as a marker of increased risk of cancer for both breasts (the "risk factor theory") [10] or a true breast cancer precursor (the "precursor theory") [11].

This review addresses the evaluation of the risk of invasive breast cancer (IBC) and ductal carcinoma in situ (DCIS) following a diagnosis of LIN. It also examines whether the characteristics of the cancers diagnosed following LIN favour "the risk factor" or "the precursor" theory.

\section{Methods}

A PubMed search was carried out on January 31, 2010. The search strategy consisted of terms "lobular intra-epithelial neoplasia", "lobular carcinoma in situ", "atypical lobular hyperplasia", combined with "breast cancer", "breast carcinoma". The search was limited to articles published in English from 1969 to the search date and resulted in an output of 1761 articles. The available abstracts were reviewed for relevance to the topic of breast cancer risk of original series of patients after LIN diagnosis. 
Since LIN was in most cases an incidental finding, it was often associated with various benign breast disease conditions that had led to the breast biopsy. However patients were only included when LIN was considered the most risk-associated pathological finding. Patients with associated DCIS and invasive breast cancers were excluded.

Where several articles referred to the same patient's series, only the last publication was taken into account. The 22 articles which met these criteria form the basis of this report.

The publications of Chuba et al [10] and Li et al [12] referred both to the SEER (Surveillance, Epidemiology, and End Results Program) with an overlapping in inclusion dates (respectively 1973 to 1998 and 1988 to 2002). The overlapping time frame prevented us from using both studies in the risk estimations. For the estimations of breast cancer risk after LIN (Tables 1 and 2) we chose to present as "Total 1" the results of all studies including Chuba et al but excluding Li et al, and as "Total 2" the results of all studies including Li et al but excluding Chuba et al. In the results and discussion sections we chose to refer to the results of all studies including Chuba et al and excluding Li et al, since the risk estimations are greater than those obtained with Li et al (except for the risk of ipsilateral IBC).

\section{Results}

\section{Cumulative risk of breast cancer after LIN}

For a women diagnosed with LIN, the cumulative average risk of metachronous breast cancer (IBC or DCIS) was $9.6 \%$ (range 0-32). The average risk of IBC was $8.7 \%$ (range 0-33) whereas the average risk of DCIS was $2.9 \%$ (range 0-13) (Table 1).

The average risk for IBC for the ipsilateral breast was $4.7 \%$ (range 0-25) which was (although slightly greater) near the level of risk for the contralateral breast that was $4.2 \%$ (range $0-16$ ). The difference in risk between the two breasts was more pronounced for the risk of DCIS that 
was $2.3 \%$ (range $0-10$ ) for the ipsilateral breast and $0.9 \%$ (range $0-4$ ) for the contralateral breast (Table 2).

\section{Relative risk of invasive breast cancer after LIN}

To answer the question whether LIN modifies the IBC risk in a woman it is necessary to compare the observed IBC incidence in LIN patients with that of the general population.

Table 3 summarizes the studies, which compared the risk of IBC in LIN patients to the risk of a referent population. Only studies with available $95 \%$ confidence intervals are reported. The relative risk was calculated by the ratio of the IBC rates observed in the LIN patients to the expected rates if IBC incidence was the same in LIN patients as it is in the population at large. The expected number of females developing IBC after LIN was calculated per year of diagnosis and age group [10, 13]. All studies were concordant to demonstrate an excess of IBC risk in LIN patients, with a relative risk ranging from 2.4 to 11.9.

\section{Modifiers of invasive breast cancer risk after LIN}

Various qualitative and quantitative pathological features were evaluated for association with IBC risk after LIN $[4,5,7,13,14,15,16]$. Higher IBC risk was only found to be associated with intense lymphocytic reaction in lobules with LIN [16], larger nuclear size [4], and pathological grade 3 or 2 according a three tired grading system [7].

Age at LIN diagnosis also modified the IBC risk in the study by Bodian et al, with an increased risk for women younger than 40 years and a decreased risk for women older than 55 years [13]. However this result was not confirmed in other studies $[10,12,17,18]$.

No association could be demonstrated between IBC risk after LIN and ethnicity, reproductive factors, or family history $[10,12,13,16]$.

\section{Characteristics of invasive breast cancers after LIN}

Fifty-two percent of breast cancer (BC) occurred more than 10 years after the initial diagnosis of LIN was made (Table 4). Compared to ipsilateral BC, contralateral BC were more 
frequently delayed. Contralateral $\mathrm{BC}$ were less frequent during the first five years and more frequent after 10 years. Compared to the general population the relative risk of IBC in the LIN patients was not dependent on the follow-up $[10,12,13,15,17,18]$. The excess of risk was almost identical up to 20 years after the LIN diagnosis $[10,13,17]$. Beyond twenty years of follow-up there were too few patients to provide valid estimations.

A lobular histotype was present in $30 \%$ (range 0 to 67 ) of all IBC recurrences (Table 1). A lobular histotype was more frequent for ipsilateral IBC (51\% range $0-100)$ than for contralateral IBC (41\% range $0-60)$.

The topography of ipsilateral IBC recurrences were only reported in 3 studies. In the study by Carson et al, one out of three recurrences were in the same quadrant as the initial LIN [19]. In the study by Cutuli et al [20], the sole ipsilateral recurrence was in the same quadrant as the initial LIN and in the series reported by Fisher et al, all the nine ipsilateral recurrences were in the same quadrant [7].

\section{Discussion}

In this review the cumulative average risk of metachronous IBC was $8.7 \%$ but with a wide variation from study to study, ranging from 0 to $33 \%$. The risk was slightly greater for the ipsilateral as compared to the contralateral breast. Tumors characteristics supported arguments both for considering LIN as a non obligatory breast cancer precursor and as a risk factor for bilateral breast cancer.

Before interpreting results of this study, it is important to acknowledge its limitations. Most of the follow-up studies of women with LIN are both small and retrospective. Studies have differed with respect to several factors including criteria for patient selection, length of follow-up, treatment of LIN and periods of inclusion (spanning from 1940 [21] to 2002 [12] ). Histological diagnoses were oftently made by community pathologists at different periods of 
time, misclassification of histologic types is likely to have occurred. DCIS following LIN were inconsistently reported $[14,17,10,12]$, and in some series it was not possible to distinguish DCIS and IBC [13]. We only recorded metachronous breast cancers, however the definition differed slightly from study to study using the term metachronous to define breast cancers occurring either more than 6 or 12 months after the initial LIN diagnosis [7, 12]. Another limitation of the current study was the impossibility due to the study design to control for the confounding factors in the estimation of IBC risk, particularly the length of follow-up and the initial treatment of the LIN.

However, the greatest limitation of the LIN series that form the basis of our review is the rarity of the disease. In our study the estimations of IBC risk are based on more than 6000 patients diagnosed with LIN.

When Foote and Stewart described LIN it was viewed as a malignancy requiring a mastectomy [3]. However, retrospective studies of archived breast biopsy specimens originally read as benign and diagnosed as LIN on review showed that most women had not developed breast cancer even after long follow-up and that invasive breast cancer did not necessarily arise in the breast where the LIN was initially diagnosed [15]. This results were confirmed by series of patients treated with excisional biopsy alone. In those series the 20 years cumulative risk was up to $33 \%$, and women with LIN were equally likely to be diagnosed with ipsilateral and contralateral invasive breast cancers $[14,15,16,22]$. The LIN was then considered as a marker of breast cancer risk. The only logical approaches under this "risk factor theory" were either a close follow-up or a bilateral mastectomy. However, bilateral mastectomy was unnecessary for the vast majority of patients, and this procedure never achieved great popularity even by the time when conservative procedures were developed for IBC [23]. 
More recently the "precursor theory" has gained popularity since it was demonstrated that LIN and invasive lobular neoplasia share the lack of expression of the E-cadherin adhesion cell molecule. This latter finding suggests a possible transformation of LIN into invasive lobular neoplasia [11].

In our study the relatively low level of risk for invasive breast cancer and the time distribution of the recurrences with more than $50 \%$ of $\mathrm{BC}$ occurring more than 10 years after the initial LIN were in favour of the risk factor theory. Another major argument was the risk of invasive contralateral breast cancer that was near the level of risk for ipsilateral invasive breast cancer. Some authors have argued that contralateral breast cancers risk was explained by the frequent bilaterality of LN. However, similar levels of risk were observed in series were contralateral breast biopsies were systematically performed at the time of the LIN diagnosis [8]. Another argument for the "risk factor theory" was that the majority of IBC following LIN do not contain any invasive lobular histotype (Table 1).

On the other hand some results of our study clearly advocate the precursor theory. Although the average level of IBC risk was low, there was a wide range in the risk between studies. The highest risks were observed in studies where no surgical procedure other than the initial excision biopsy were performed. It has been demonstrated that residual LIN was present in the majority of cases after excisional biopsy [24]. This results suggested that the removal of the initial LIN may be beneficial. As previously stated the risk of IBC for the ipsilateral breast was near the level observed for the contralateral breast. However, in most series it was slightly lower (Table 2). This could be in keeping with an evolution of the LIN into IBC in some women. Although not predominant, lobular invasive breast cancer was over represented in IBC recurrences since it was observed in $30 \%$ of cases, whereas it only represents $16 \%$ of IBC in the general population [1]. Moreover lobular invasive breast cancers were more frequent in the ipsilateral breast $(51 \%)$ as compared to the contralateral $(41 \%)$. Finally the 
topography of the ipsilateral IBC recurrences brought another argument for the precursor theory since there were in most cases in the same quadrant as the initial LIN [7].

In this review LIN patients had a relative risk of IBC that was 2 to 4 folds that of the general population, except in the study of Andersen et al [17]. Since the majority of LIN patients will ultimately not develop an IBC, the identification of subgroups of patients at increased risk would be helpful to tailor the initial treatment. Studies that have attempted to identify IBC risk modifiers in LIN patients have however yielded either inconclusive or conflicting results. An exception is exemplified by the pathological grading system proposed by Fisher et al [7], which however requires confirmation in further studies.

\section{Conclusions}

This review of the current data on LIN presents strong arguments for LIN both as a precursor and a risk factor for IBC. In the author's opinion, consideration of the precursor argument makes it logical to attempt to remove the LIN. However, the risk factor aspect with a low level of risk and a risk for contralateral breast cancer argue in our opinion for a lumpectomy rather than a mastectomy, and a close follow-up. Further evaluations are required to evaluate the potential benefit of the removal of the LIN, the role of free margins, and to identify IBC risk modifiers among LIN patients.

\section{Conflict of interest statement}

The authors state that they have no conflict of interest 


\section{References}

1.Tavassoli FA, Millis RR, Boecker W, Lakhani SR. Lobular Neoplasia. In Tavassoli FA,

Devilee P, editors. World Health Organization Classification of Tumors. Pathology and Genetics of Tumors of the Breast and Female Genital Organs. Lyon: IARC Press, 2003. pp: $60-2$.

2.Li CI, Daling JR, Malone KE. Age specific incidence rates of in situ breast carcinomas by histologic type, 1980 to 2001. Cancer Epidemiol Biomarkers Prev 2005; 14: 1008-11.

3.Foote FWJ, Steewart FW. Lobular carcinoma in situ. A rare form of mammary cancer. Am J Pathol 1941: 17: 491-6.

4.Ottesen GL, Graversen HP, Blichert-Toft M, Christensen IJ, Andersen JA. Carcinoma in situ of the female breast. 10 years follow-up results of a prospective nationwide study. Breast Cancer Res Treat 2000; 62: 197-210.

5.Goldstein NS, Kestin LL, Vicini FA. Clinicopathologic implications of E-cadherin reactivity in patients with lobular carcinoma in situ of the breast. Cancer 2001; 92: 738-47.

6.Page DL, Schuyler PA, Dupont WD, Jensen RA, Plummer WDJr, Simpson JF. Atypical lobular hyperplasia as a unilateral predictor of breast cancer risk: a retrospective cohort study. Lancet $2003 ; 361: 125-9$. 
7.Fisher ER, Land SR, Fisher B, Mamounas E, Gilarski L, Wolmark N. Pathologic findings from the National Surgical Adjuvant Breast and Bowel Project: twelve-year observations concerning lobular carcinoma in situ. Cancer 2004; 100: 238-44.

8.Rosen PP, Braun DW, Lyngholm B, Urban JA, Kinne DW. Lobular carcinoma in situ of the breast: preliminary results of treatment by ipsilateral mastectomy and contralateral breast biopsy. Cancer 1981; 47: 813-9.

9.Leis HP, Mersheimer WL, Black MM, Chabon A. The second breast. N Y State J Med 1965; 65: 2460-8.

10.Chuba PJ, Hamre MR, Yap J, Severson RK, Lucas D, Shamsa F, Aref A.. Bilateral risk for subsequent breast cancer after lobular carcinoma in situ. J Clin Oncol 2005; 23: 5534-41.

11.Acs G, Lawton TS, Rebbeck TR, LiVosli VA, Shang PJ. Differential expression of Ecadherin in lobular and ductal neoplasms of the breast and its biologic and diagnostic implications. Am J Clin Pathol 2001; 115: 85-98.

12.Li C, Malone KE, Saltzman BS, Daling JR. Risk of invasive breast carcinoma among women diagnosed with ductal carcinoma in situ and lobular carcinoma in situ, 1998-2001. Cancer 2006; 106: 2104-12.

13.Bodian CA, Perzin KH, Lattes R. Lobular neoplasia: long term risk of breast cancer and relation to other factors. Cancer 1996; 78: 1024-34. 
14.Wheeler JE, Enterline HT, Roseman JM, Tomasulo JP, McIlvaine CH, Fitts WTJr,

Kirschenbaum J. Lobular carcinoma in situ of the breast. Long term follow-up. Cancer 1974; 34: 554-63.

15.Haagensen CD, Lane N, Lattes R, Bodian C. Lobular neoplasia (so called lobular carcinoma in situ) of the breast. Cancer 1978; 42: 737-69.

16.Rosen PP, Lieberman PH, Braun DW, Kosloff C, Adair F. Lobular carcinoma in situ of the breast. Am J surg Pathol 1978; 2: 225-51.

17.Andersen JA. Lobular carcinoma in situ of the breast: an approach to rational treatment. Cancer 1977; 39: 2597-2602.

18.Levi F, Randimbison L, Te VC, La Vecchia C. Invasive breast cancer following ductal and lobular carcinoma in situ of the breast. Int J Cancer 2005; 116: 820-3.

19.Carson W, Sanchez-Forgach E, Stomper P, Penetrante R, Tsangaris TN, Edge SB. Lobular carcinoma in situ: observation without surgery as an appropriate therapy. Ann Surg Oncol 1994; 1: 141-6.

20.Cutuli B, de Lafontan B, Quetin P, Mery E. Breast conserving surgery and radiotherapy : a possible treatment for lobular carcinoma in situ ? Eur J Cancer 2005; 41: 380-5.

21.Hutter RV, Foote FW. Lobular carcinoma in situ: long term follow up. Cancer 1969; 24: 1081-5. 
22.McDivitt RW, Hutter RV, Foote FWJr, Stewart FW. In situ lobular carcinoma: a prospective follow-up study indicating cumulative patient risks. Jama 1967; 201: 82-6.

23.Goldschmidt RA, Victor TA. Lobular carcinoma in situ of the breast. Semin Surg Oncol 1996; 12: 314-20.

24.Warner NE. Lobular carcinoma of the breast. Cancer 1969; 23: 840-5.

25.Curletti E, Giordano J. In situ lobular carcinoma of the breast. Arch Surg 1981; 116: 30910.

26.Sunshine JA, Moseley HS, Fletcher WS, Krippaehne WW. Breast carcinoma in situ, a retrospective review of 112 cases with a minimum 10 year follow-up. Am J Surg 1985; 150: $44-51$

27.Ringberg A, Andersson I, Aspegren K, Linell F. Breast carcinoma in situ in 167 womenincidence, mode of presentation, therapy and follow-up. Eur J Surg Oncol 1991; 17: 466-76.

28.Graham MD, Lakhani S, Gazet JC. Breast conserving surgery in the management of in situ breast carcinoma. Eur J Surg Oncol 1991; 17: 258-64.

29.Ciatto S, Cataliotti L, Cardona G, Bianchi S. Risk of infiltrating breast cancer subsequent to lobular carcinoma. Tumori 1992; 78: 244-6. 
30.Zurrida S, Bartoli C, Galimberti V, Raselli R, Barletta L. Interpretation of the risk associated with the unexpected finding of lobular carcinoma in situ. Ann Surg Oncol 1996; 3: 57-61. 
Table 1: Risk of metachrone breast cancer after lobular intraepithelial neoplasia (LIN)

\begin{tabular}{|c|c|c|c|c|c|c|c|}
\hline Author, year & $\begin{array}{l}\text { Follow- } \\
\text { up } \\
\text { (years) }\end{array}$ & LIN & $\begin{array}{c}\text { Ipsilateral } \\
\text { mastectomy } \\
\mathrm{N}(\%)\end{array}$ & $\begin{array}{l}\text { Women } \\
\text { with } \\
\text { recurrence } \\
\text { (inv + } \\
\text { DCIS) N } \\
(\%)\end{array}$ & $\begin{array}{l}\text { DCIS } \\
\mathrm{N}(\%)\end{array}$ & $\begin{array}{c}\text { Invasive } \\
\text { breast cancer } \\
\mathrm{N}(\%)\end{array}$ & $\begin{array}{c}\text { Invasive } \\
\text { lobular } \mathrm{N} \\
(\%)\end{array}$ \\
\hline Hutter, 1969 [21] & $4-27 * *$ & 46 & $6(13)$ & $15(32)$ & $6(13)$ & $14(30)$ & - \\
\hline $\begin{array}{l}\text { Wheeler, } 1974 \\
{[14]}\end{array}$ & $16 \S$ & 38 & $13(34)$ & $4(11)$ & - & $4(11)$ & $1(25)$ \\
\hline $\begin{array}{l}\text { Andersen, } 1977 \\
\text { [17] }\end{array}$ & $16 \S$ & 47 & $3(6)$ & $10(21)$ & - & $12(26)$ & - \\
\hline $\begin{array}{l}\text { Haagensen, } 1978 \\
{[15]}\end{array}$ & $14 \S$ & 211 & $18(9)$ & $36(17)$ & $9(4)$ & $30(14)$ & $19(63)$ \\
\hline Rosen, 1978 [16] & $24 \S$ & 99 & $0(0)$ & $32(32)$ & $2(2)$ & $33(33)$ & $13(39)$ \\
\hline Curletti 1981 [25] & $7-21 * *$ & 19 & $0(0)$ & $2(11)$ & - & $2(11)$ & - \\
\hline Rosen, 1981 [8] & $15 \S$ & 101 & $84(84)$ & $8(8)$ & $1(1)$ & $7(7)$ & $1(14)$ \\
\hline $\begin{array}{l}\text { Sunshine, } 1985 \\
\text { [26] }\end{array}$ & $12 \mathrm{~min}$ & 36 & $33(92)$ & 0 & 0 & 0 & 0 \\
\hline $\begin{array}{l}\text { Ringberg, } 1991 \\
\text { [27] }\end{array}$ & $8 *$ & 33 & $22(67)$ & $1(3)$ & 0 & $1(3)$ & 0 \\
\hline Graham, 1991 [28] & $6 \S$ & 20 & $0(0)$ & $1(5)$ & 0 & $1(5)$ & 0 \\
\hline Ciatto, 1992 [29] & $5 \S$ & 60 & $23(38)$ & $6(10)$ & $1(2)$ & $5(8)$ & - \\
\hline Carson, 1994 [19] & $7^{*}$ & 60 & $9(15)$ & $3(5)$ & $2(3)$ & $3(5)$ & $2(67)$ \\
\hline Zurrida, 1996 [30] & $4^{*}$ & 157 & $22(14)$ & $10(6)$ & $0(0)$ & $10(6)$ & $4(40)$ \\
\hline Bodian, 1996 [13] & $18^{*}$ & 234 & $20(9)$ & $62(26)$ & - & - & $12 / 45(27)$ \\
\hline Ottesen, 2000 [4] & $12 *$ & 100 & $0(0)$ & $18(18)$ & $5(5)$ & $13(13)$ & $3(23)$ \\
\hline $\begin{array}{l}\text { Goldstein, } 2001 \\
\text { [5] }\end{array}$ & $22 \S$ & 82 & $0(0)$ & $16(20)$ & $1(1)$ & $20(24)$ & $11(55)$ \\
\hline Page, 2003 [6] & $18-53 * *$ & 161 & $0(0)$ & $25(16)$ & - & $26(16)$ & - \\
\hline Fisher, 2004 [7] & $17 \mathrm{~min}$ & 180 & $0(0)$ & $26(14)$ & $10(6)$ & $19(10)$ & $14(74)$ \\
\hline Levi, 2005 [18] & $3-28 * *$ & 88 & - & $8(9)$ & - & $8(9)$ & - \\
\hline Cutuli, 2005 [20] & $13 *$ & 25 & $0(0)$ & $2(8)$ & $0(0)$ & $2(8)$ & $0(0)$ \\
\hline Chuba, 2005 [10] & $7-31 * *$ & 4853 & $\begin{array}{l}1281 / 4600 \\
(28)\end{array}$ & $\begin{array}{c}350 / 4853 \\
(7)\end{array}$ & - & $350 / 4853(7)$ & $\begin{array}{l}81 / 350 \\
(23)\end{array}$ \\
\hline $\mathrm{Li}, 2006$ [12] & $3-17 * *$ & 4490 & - & $282(6)$ & - & $282 / 4490(6)$ & $\begin{array}{l}119 / 242 \\
(49)\end{array}$ \\
\hline $\begin{array}{l}\text { Total } 1 \text { (with } \\
\text { Chuba and without } \\
\text { Li) }\end{array}$ & 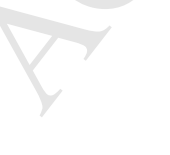 & 6650 & $\begin{array}{c}1534 / 6397 \\
\mathbf{2 4 \%}\end{array}$ & $\begin{array}{c}\text { 635/6650 } \\
\mathbf{9 . 6 \%}\end{array}$ & $\begin{array}{c}37 / 1270 \\
\mathbf{2 . 9 \%}\end{array}$ & $\begin{array}{c}560 / 6416 \\
\mathbf{8 . 7 \%}\end{array}$ & $\begin{array}{c}161 / 538 \\
\mathbf{3 0 \%}\end{array}$ \\
\hline $\begin{array}{l}\text { Total } 2 \text { (with Li } \\
\text { and without } \\
\text { Chuba) }\end{array}$ & & 6287 & $\begin{array}{c}253 / 1797 \\
14 \%\end{array}$ & $\begin{array}{c}567 / 6287 \\
\mathbf{9 \%}\end{array}$ & $\begin{array}{c}37 / 1270 \\
\mathbf{2 . 9 \%}\end{array}$ & $\begin{array}{c}492 / 6053 \\
\mathbf{8 . 1 \%}\end{array}$ & $\begin{array}{c}199 / 430 \\
\mathbf{4 6 \%}\end{array}$ \\
\hline
\end{tabular}

Legend :

-Since the study of Chuba et al, and Li et al al referred both to the same population with an overlapping in inclusion dates the Total 1 involves all studies except $\mathrm{Li}$ et al and the Total 2 involves all studies except Chuba et al. 
-Expression of follow-up*median, §mean, **minimal and maximal follow-up -In the study of Sunshine one patient died from metastases after ipsilateral mastectomy without contralateral breast cancer. 
Table 2: Risk of ipsilateral and contralateral metachrone breast cancer after lobular intraepithelial neoplasia (LIN)

\begin{tabular}{|c|c|c|c|c|c|c|c|c|c|}
\hline \multirow[t]{2}{*}{ Author, year } & \multirow{2}{*}{$\begin{array}{l}\text { Follow- } \\
\text { up } \\
\text { (years) }\end{array}$} & \multicolumn{4}{|c|}{ Ipsilateral breast cancer } & \multicolumn{4}{|c|}{ Contralateral breast cancer } \\
\hline & & $\begin{array}{l}\text { Wom } \\
\text { en at } \\
\text { risk }\end{array}$ & DCIS & $\begin{array}{l}\text { Invasive } \\
\text { rec } \mathrm{N}(\%)\end{array}$ & $\begin{array}{c}\text { Invasive } \\
\text { lobular } \\
\mathrm{N}(\%)\end{array}$ & $\begin{array}{c}\text { Women } \\
\text { at risk }\end{array}$ & DCIS & $\begin{array}{l}\text { Invasive } \\
\text { rec } \mathrm{N}(\%)\end{array}$ & $\begin{array}{c}\text { Invasive } \\
\text { lobular } \\
\mathrm{N}(\%)\end{array}$ \\
\hline $\begin{array}{l}\text { Hutter, } 1969 \\
\text { [21] }\end{array}$ & $4-27$ & 40 & $4(10)$ & $10(25)$ & - & 46 & $2(4)$ & $4(9)$ & - \\
\hline $\begin{array}{l}\text { Wheeler, } 1974 \\
{[14]}\end{array}$ & $16 \S$ & 25 & - & $1(4)$ & $1(100)$ & 32 & & $3(9)$ & $0(0)$ \\
\hline $\begin{array}{l}\text { Andersen, } 1977 \\
\text { [17] }\end{array}$ & $16 \S$ & 44 & - & $8(18)$ & - & 47 & & $4(9)$ & - \\
\hline $\begin{array}{l}\text { Haagensen, } 1978 \\
{[15]}\end{array}$ & $14 \S$ & 193 & - & - & - & 205 & & - & - \\
\hline Rosen, 1978 [16] & $24 \S$ & 99 & $1(1)$ & $17(17)$ & $8(47)$ & 99 & $1(1)$ & $16(16)$ & $5(31)$ \\
\hline Rosen, 1981 [8] & $15 \S$ & 17 & $0(0)$ & $2(12)$ & $1(50)$ & 101 & $1(1)$ & $5(5)$ & $0(0)$ \\
\hline $\begin{array}{l}\text { Sunshine, } 1985 \\
{[26]}\end{array}$ & $12 \min$ & 3 & 0 & 0 & 0 & 15 & 0 & 0 & 0 \\
\hline $\begin{array}{l}\text { Ringberg, } 1991 \\
\text { [27] }\end{array}$ & $8 *$ & 11 & 0 & $1(9)$ & 0 & 15 & 0 & 0 & 0 \\
\hline $\begin{array}{l}\text { Graham, } 1991 \\
\text { [28] }\end{array}$ & $6 \S$ & 20 & 0 & $1(5)$ & 0 & 20 & 0 & 0 & 0 \\
\hline Ciatto, 1992 [29] & $5 \S$ & 37 & $0(0)$ & $4(11)$ & $2(50)$ & 60 & $1(2)$ & $1(2)$ & - \\
\hline $\begin{array}{l}\text { Carson, } 1994 \\
\text { [19] }\end{array}$ & $7 *$ & 51 & $1(2)$ & $3(6)$ & $2(75)$ & 60 & $1(2)$ & $0(0)$ & $0(0)$ \\
\hline $\begin{array}{l}\text { Zurrida, } 1996 \\
\text { [30] }\end{array}$ & $4^{*}$ & 135 & $0(0)$ & $4(3)$ & $2(50)$ & 157 & $0(0)$ & $6(4)$ & $2(33)$ \\
\hline $\begin{array}{l}\text { Ottesen, } 2000 \\
\text { [4] }\end{array}$ & $12 *$ & 100 & $5(5)$ & $11(11)$ & $3(27)$ & 100 & $0(0)$ & $2(2)$ & $0(0)$ \\
\hline $\begin{array}{l}\text { Goldstein, } 2001 \\
\text { [5] }\end{array}$ & $22 \S$ & 82 & $1(1)$ & $13(16)$ & $7(54)$ & 82 & $0(0)$ & $7(9)$ & $4(57)$ \\
\hline Page, 2003 [6] & $18-53$ & 161 & . & $18(11)$ & - & 161 & - & $6(4)$ & - \\
\hline Fisher, 2004 [7] & $17 \min$ & 180 & $7(4)$ & $9(5)$ & $8(89)$ & 180 & $3(2)$ & $10(6)$ & $6(60)$ \\
\hline Cutuli, 2005 [20] & $13^{*}$ & 25 & $0(0)$ & $1(4)$ & $0(0)$ & 25 & $0(0)$ & $1(4)$ & $0(0)$ \\
\hline $\begin{array}{l}\text { Chuba, } 2005 \\
\text { [10] }\end{array}$ & $7-31$ & 3141 & - & $93(3)$ & - & 4422 & - & $\begin{array}{c}171 / 4420 \\
(4)\end{array}$ & - \\
\hline $\mathrm{Li}, 2006$ [12] & $3-17 * *$ & 4490 & - & $1654)$ & - & 4490 & - & $\begin{array}{c}116 / 4490 \\
(2.6)\end{array}$ & - \\
\hline Total 1 (with & & 4364 & $19 / 800$ & $196 / 4171$ & $34 / 67$ & $\mathbf{5 8 2 7}$ & $9 / 960$ & $236 / 5620$ & $17 / 41$ \\
\hline $\begin{array}{l}\text { Chuba and } \\
\text { without Li) }\end{array}$ & & & $2.3 \%$ & $4.7 \%$ & $51 \%$ & & $0.9 \%$ & $4.2 \%$ & $41 \%$ \\
\hline $\begin{array}{l}\text { Total } 2 \text { (with Li } \\
\text { and without } \\
\text { Chuba }\end{array}$ & & 5713 & $\begin{array}{c}19 / 800 \\
\mathbf{2 . 3 \%}\end{array}$ & $\begin{array}{c}268 / 5520 \\
\mathbf{4 . 9 \%}\end{array}$ & $\begin{array}{l}34 / 67 \\
\mathbf{5 1 \%}\end{array}$ & 5895 & $\begin{array}{l}9 / 960 \\
0.9 \%\end{array}$ & $\begin{array}{c}181 / 5960 \\
\mathbf{3 . 0 \%}\end{array}$ & $\begin{array}{l}17 / 41 \\
\mathbf{4 1 \%}\end{array}$ \\
\hline
\end{tabular}


Legend :

-Since the study of Chuba et al, and $\mathrm{Li}$ et al al referred both to the same population with an overlapping in inclusion dates the Total 1 involves all studies except Li et al and the Total 2 involves all studies except Chuba et al.

-Expression of follow-up:*median, §mean, **minimal and maximal follow-up

-"Women at risk" for the ipsilateral breast, or for the contralateral breast, are women who at the time of LIN diagnosis had no mastectomy of the ipsilateral breast or of the contralateral breast, respectively.

-rec: recurrence 
Table 3: Relative risk of invasive breast cancer (IBC) after lobular intraepithelial neoplasia (LIN)

\begin{tabular}{|l|c|c|c|c|}
\hline author, year & $\begin{array}{c}\text { number of } \\
\text { observed IBC }\end{array}$ & $\begin{array}{c}\text { number of } \\
\text { expected IBC }\end{array}$ & $\begin{array}{c}\text { Ratio observed to } \\
\text { expected }\end{array}$ & $\begin{array}{c}\text { 95\% confident } \\
\text { interval }\end{array}$ \\
\hline Andersen, 1977 & 11 & 0.9 & $11.9^{*}$ & $6.3-19.2$ \\
[17] & - & - & $2.6^{* *}$ & $1.7-3.9$ \\
Page, 2003 [6] & 8 & 1.7 & $4.2 \S$ & $2.1-7.5$ \\
Levi, 2005 [18] & - & - & $2.4 \S$ & $2.1-2.3$ \\
Chuba, 2005 [10] & & & & \\
\hline
\end{tabular}

Legend: The ratio observed to expected (number of IBC observed in the study group of women with a past history of LIN to the number of IBC expected in this group on the basis of incidence rates in the general population) was expressed either as the Relative Risk (*), the hazard ratio (**) or the Standardized Incidence Ratio (§), according to the study design. 
Table 4. Time interval until subsequent carcinoma after lobular intraepithelial neoplasia (LIN)

\begin{tabular}{|c|c|c|c|c|c|c|c|c|c|c|c|c|}
\hline \multirow{2}{*}{$\begin{array}{l}\text { Author, } \\
\text { year }\end{array}$} & \multicolumn{4}{|c|}{ Overall cancers } & \multicolumn{4}{|c|}{ Ipsilateral cancers } & \multicolumn{4}{|c|}{ Contralateral cancers } \\
\hline & $\mathrm{N}$ & $\begin{array}{c}1 \text { to } \\
\leq 5 \mathrm{yrs}\end{array}$ & $\begin{array}{l}6 \text { to } \\
\leq 10 \\
\text { yrs }\end{array}$ & $\begin{array}{l}>10 \\
\text { yrs }\end{array}$ & $\mathrm{N}$ & $\begin{array}{c}1 \text { to } \\
\leq 5 \mathrm{yrs}\end{array}$ & $\begin{array}{l}6 \text { to } \\
\leq 10 \\
\text { yrs }\end{array}$ & $\begin{array}{l}>10 \\
\text { yrs }\end{array}$ & $\mathrm{N}$ & $\begin{array}{c}1 \text { to } \\
\leq 5 \mathrm{yrs}\end{array}$ & $\begin{array}{l}6 \text { to } \\
\leq 10 \\
\text { yrs }\end{array}$ & $\begin{array}{l}>10 \\
\text { yrs }\end{array}$ \\
\hline $\begin{array}{l}\text { Hutter, } \\
1969 \text { [21] }\end{array}$ & 20 & 6 & 4 & 10 & 14 & 5 & 2 & 7 & 6 & 1 & 2 & 3 \\
\hline $\begin{array}{l}\text { Wheeler, } \\
1974 \text { [14] }\end{array}$ & 4 & 0 & 2 & 2 & 1 & 0 & 0 & 1 & 3 & 0 & 2 & 1 \\
\hline $\begin{array}{l}\text { Andersen, } \\
1977 \text { [17] }\end{array}$ & 12 & 3 & 3 & 6 & 8 & 3 & 1 & 4 & 4 & 0 & 2 & 2 \\
\hline $\begin{array}{l}\text { Haagensen, } \\
1978 \text { [15] }\end{array}$ & 35 & 15 & 6 & 14 & 19 & 6 & 5 & 8 & 16 & 9 & 1 & 6 \\
\hline $\begin{array}{l}\text { Rosen, } \\
1978 \text { [16] }\end{array}$ & 35 & 3 & 7 & 25 & 19 & 2 & 3 & 14 & 16 & 1 & 4 & 11 \\
\hline $\begin{array}{l}\text { Ringberg, } \\
1991 \text { [27] }\end{array}$ & 1 & 1 & 0 & 0 & 1 & 1 & 0 & 0 & 0 & 0 & 0 & 0 \\
\hline $\begin{array}{l}\text { Graham, } \\
1991 \text { [28] }\end{array}$ & 1 & 1 & 0 & 0 & 1 & 1 & 0 & 0 & 0 & 0 & 0 & 0 \\
\hline $\begin{array}{l}\text { Ciatto, } \\
1992 \text { [29] }\end{array}$ & - & - & - & - & 4 & 3 & 1 & 0 & - & - & - & - \\
\hline $\begin{array}{l}\text { Carson, } \\
1994 \text { [19] }\end{array}$ & 3 & 2 & 1 & 0 & 3 & 2 & 1 & 0 & 0 & 0 & 0 & 0 \\
\hline $\begin{array}{l}\text { Zurrida, } \\
1996 \text { [30] }\end{array}$ & 10 & 5 & 5 & 0 & 4 & 3 & 1 & 0 & 6 & 2 & 4 & 0 \\
\hline $\begin{array}{l}\text { Bodian, } \\
1996 \text { [13] }\end{array}$ & 62 & 10 & 19 & 33 & - & - & - & - & - & - & - & - \\
\hline $\begin{array}{l}\text { Goldstein, } \\
2001 \text { [5] }\end{array}$ & 21 & 2 & 5 & 14 & - & - & - & - & - & - & - & - \\
\hline $\begin{array}{l}\text { Fisher, } \\
2004 \text { [7] }\end{array}$ & 19 & 8 & 7 & 4 & 9 & 5 & 4 & 0 & 10 & 3 & 3 & 4 \\
\hline $\begin{array}{l}\text { Cutuli, } \\
2005[20]\end{array}$ & 2 & 1 & 0 & 1 & 1 & 0 & 0 & 1 & 1 & 1 & 0 & 0 \\
\hline $\begin{array}{l}\text { Chuba, } \\
2005 \text { [10] }\end{array}$ & 265 & 34 & 83 & 148 & 99 & 13 & 34 & 52 & 166 & 21 & 49 & 96 \\
\hline Total & 490 & $\begin{array}{c}91 \\
(\mathbf{1 9 \%})\end{array}$ & $\begin{array}{c}144 \\
(29 \%)\end{array}$ & $\begin{array}{c}257 \\
(\mathbf{5 2 \%})\end{array}$ & 183 & $\begin{array}{c}44 \\
(\mathbf{2 4 \%})\end{array}$ & $\begin{array}{c}52 \\
(\mathbf{2 8 \%})\end{array}$ & $\begin{array}{c}87 \\
(\mathbf{4 8 \%})\end{array}$ & 228 & $\begin{array}{c}38 \\
(\mathbf{1 7 \%})\end{array}$ & $\begin{array}{c}67 \\
(\mathbf{2 9 \%}) \\
\end{array}$ & $\begin{array}{c}123 \\
(\mathbf{5 4 \%})\end{array}$ \\
\hline
\end{tabular}

